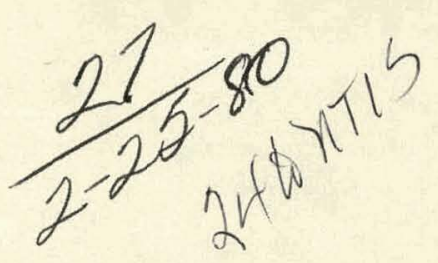

ANL/ CNSV-TM-28

\title{
PROCEDURES FOR SAFE HANDLING OF OFF-GASES FROM ELECTRIC VEHICLE LEAD-ACID BATTERIES DURING OVERCHARGE
}

by

S.J. LaBelle, M.H. Bhattacharyya, R.0. Loutfy, and R. Varma Energy \& Environmental Systems, Biological \& Medical Research, and Chemical Engineering Divisions

ARGONNE NATIONAL LABORATORY

Argonne, Illinois 60439

January 25, 1980

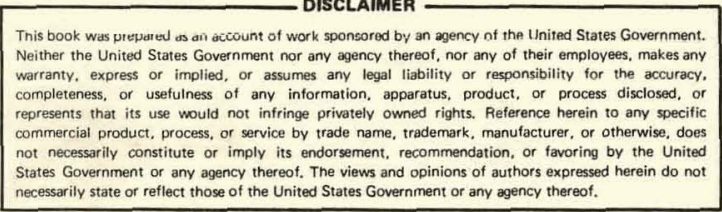

\author{
prepared for \\ U.S. DEPARTMENT OF ENERGY \\ Assistant Secretary for Conservation and Solar Energy \\ office of Transportation Programs \\ under Contract W-31-109-Eng-38
}




\section{DISCLAIMER}

This report was prepared as an account of work sponsored by an agency of the United States Government. Neither the United States Government nor any agency Thereof, nor any of their employees, makes any warranty, express or implied, or assumes any legal liability or responsibility for the accuracy, completeness, or usefulness of any information, apparatus, product, or process disclosed, or represents that its use would not infringe privately owned rights. Reference herein to any specific commercial product, process, or service by trade name, trademark, manufacturer, or otherwise does not necessarily constitute or imply its endorsement, recommendation, or favoring by the United States Government or any agency thereof. The views and opinions of authors expressed herein do not necessarily state or reflect those of the United States Government or any agency thereof. 


\section{DISCLAIMER}

Portions of this document may be illegible in electronic image products. Images are produced from the best available original document. 


\section{PAGES 1 i to ii WERE INTENTIONALLY LEFT BLANK}


OVERVIEW.............................................

1 Is There Any Hazard to Users and Maintenance Staff Now? ............ 2

1.1 Demonstration and Testing Can Proceed ..................... 2

1.2 How to Identify Unexpected High Emissions .................. 3

1.3 Safeguards from Possible Accumulation of Low Level Emissions ...... 3

2 Why Are Stibine and Arsine Gases Important to Designers and Users of

Electric Vehicles?.......................................6

2.1 Presence of the Metals in the Lead-Acid Battery ............. 6

2.2 The Equalization Charge in Electric Vehicle Batteries...........6 6

2.3 Health Effects of Stibine \& Arsine ....................... 8

2.3.1 Pathways to Humans and Toxic Levels .................. 8

2.3.2 Source of Health Effects Data ....................... 10

2.4 Long-Term Prospects for Lead Acid Batteries in Electric Vehicles .. 11

3 Research to Resolve Remaining Questions ........................ 12

3.1 Criteria for Experiments ............................. 12

3.2 Experiment Design and Schedule $\ldots \ldots \ldots \ldots \ldots \ldots \ldots \ldots \ldots \ldots \ldots \ldots \ldots \ldots \ldots$

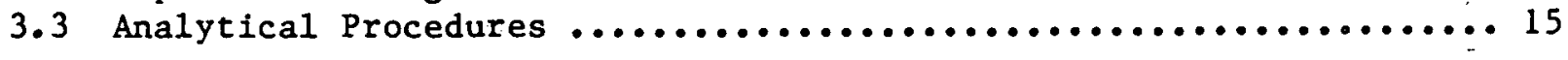

Acknowledgements $\ldots \ldots \ldots \ldots \ldots \ldots \ldots \ldots \ldots \ldots \ldots \ldots \ldots \ldots \ldots \ldots \ldots \ldots \ldots \ldots \ldots \ldots \ldots \ldots \ldots \ldots . \ldots$

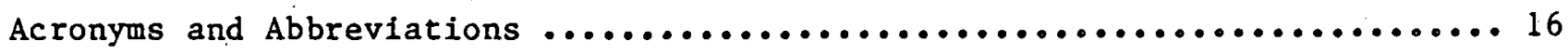

References $\ldots \ldots \ldots \ldots \ldots \ldots \ldots \ldots \ldots \ldots \ldots \ldots \ldots \ldots \ldots \ldots \ldots \ldots \ldots \ldots \ldots \ldots \ldots \ldots \ldots \ldots \ldots$ 
OVERV IEW

The potential for generation of toxic gases from lead-acid batteries has long been recognized. Prior to, the current interest in electric vehicles, there were no studies specifically oriented to toxic gas release from traction batteries, however. As the Department of Energy Demonstration Project (in the Electric and Hybrid Vehicle Program) progresses, available data from past studies and parallel health effects programs must be digested into guidance to the drivers and maintenance personnel, tailored to their contact with electric vehicles.

This brief paper presents the basic aspects of lead-acid battery operation, vehicle use, and health effects of stibine and arsine to provide electric vehicle users with the information behind our judgment that vehicle operation and testing may proceed. Specifically, we conclude that stibine generation or arsine generation at rapid enough rates to induce acute toxic response is not at all likely. Procedures to guard against low level exposure until more definitive data on ambient concentrations of the gases are collected are presented in this report for both charging the batteries and driving the vehicles. A research plan to collect additional quantitative data from electric traction batteries is presented here; Argonne National Laboratory will carry out the research over the next few months. The results will be presented to the Department of Energy for review and possible revision of the procedures. 
PROCEDURES FOR SAFE HANDLING OF OFF-GASES

FROM ELECTRIC VEHICLE LEAD-ACID BATTERIES

DURING OVERCHARGE

1 IS THERE ANY HAZARD TO USERS AND MAINTENANCE STAFF NOW?

\subsection{DEMONSTRATION AND TESTING CAN PROCEED}

Exposure to acute levels of stibine or arsine gas is virtually impossible as a result of battery charging or operation of electric vehicles available to demonstration site operators. Until results of the experiments outlined in the last section of this report are avallable, definitive quantitative statements pertaining to possible exposure to levels lower than but near the Threshold Iimit Value (TLV) cannot be made. However, monitoring and ventilation procedures described in this section provide certain information to electric vehicle (EV) maintenance and testing personnel, and drivers, on the handling of stibine gas if it should be present at levels above the TLV in the charging area or the vehicle interior. Because exposure is possible only to short term - low levels, personnel can continue to take voltage or state-of-charge measurements and operate vehicles after equalization charges by following the simple procedures described here. In any event, there are no known symptoms or significant health effects from low level exposure to either gas. It is expected that these procedures will be modified upon analysis of the data to be collected in the next few months. 


\subsection{HOW TO IDENTIFY UNEXPECTED HIGH EMISSIONS}

Emission rates from lead-acid batteries are in the range of low-level exposures, near the TLV-TWA. There is no experience to support the possibility of exposure to acute toxic levels of either gas from electric vehicle batteries. At the present, there is one crude indicator of the possible release rates for stibine - the percent of antimony in the electrode; as it increases, the release rates will also rise (but not in any simply expressed ratio). Cell voltage above $2.45 \mathrm{~V}$ also suggests higher release rates. As the first piece of information may be difficult to obtain and obtaining the second requires metering every cell in the battery pack, neither is a very useful indicator for actual operation or testing situations. Instead, monitoring and ventilation provide the best means both to know the level of stibine in the testing area and to prevent accumulation of ambient concentrations close to or above the TLV. The procedures listed below for measurement of low-level emissions and possible accumulations will also protect maintenance personnel and drivers from exposure to stibine.

Stibine can also be produced during regenerative braking (if the vehicle is so equipped), when a freshly charged battery is being overcharged during vehicle deceleration. Very low amounts have been detected; vehicle ventilation systems to remove $\mathrm{H}_{2}$ produced during regenerative braking will also disperse stibine away from the vehicle interior for dilution in the atmosphere, in addition to the air flow through the vehicle due to its own motion (ram air flow).

\subsection{SAFEGUARDS FROM POSSIBLE ACCUMULATION OF LOW LEVEL EMISSIONS}

The procedures are based on the effectiveness of ventilation in diluting stibine, and the fact that brief exposures to low levels, at or below the TLV-STEL, show no detectable effect. As long as the antinomy remains in the form of stibine gas, the concentration can be kept below the TLV by ventilation. The gaseous form disperses easily; increased air flow will diluce the concentration to safe levels. Further, adequate ventilation will remove 
the gas so that any decomposition into particulates (e.g., $\mathrm{Sb}_{2} \mathrm{O}_{3}$ ) will be lessened and slowed. (Decomposition is a non-linear function of concentration, slowest at lower concentrations.) Following these few precautionary measures will allow safe testing, charging and operation of EVs.

DURING RECHARGE

1. Maintain a minimum of three air charges per hour in the garage during recharge and equalization charge. This is converted to fan capacity (in cfm) by multiplying room volume by 3 and dividing by 60 . Insure that the air leakage into the garage does not significantly restrict the air flow through the fan. Note that most fleet garages will have adequate air flow already if gasoline vehicles are stored. This is necessary to dilute carbon monoxide in the exhaust fumes from those vehicles. If the garage ventilation system fails, stop charging as soon as possible and open doors and windows before entering garage.

2. The EV ventilation system in place for compliance with the performance standards regarding hydrogen concentration must be fully operational during all recharging. If the $\mathrm{EV}$ has a ventilating fan for this purpose, charging should cease when the fan is not operating.

3. During and immediately after equalization charge, limit the time for perpersonnel in the garage with the EVs to 15 min periods. Specific gravity readings can be taken to detarmine when equalization is complete, but personnel may be limited to sampling 3-5 cells per battery pack instead of checking every cell to stay within the 15 min time interval.

4. If the passenger compartment is fully separated from the battery compartment, positioning of the EV windows during recharge is unimportant. If If there is any uncertainty regarding the effectiveness of that seal, leave the EV windows open so that the garage ventilation will prevail.

5. Real time monitoring of stibine levels can be done with colorimetric techniques. The ANL Field Kit or a NIOSH-approver method for stibine will verify if the level of SbH3 is below the TLV. 
6. During battery discharge and stand, no off-gasing is possible; thus no precaution is necessary during driving (acceleration, cruise or stopping).

7. During regenerative braking, the ventilation system in place for hydrogen dispersion must be operating. Ram air, from EV motion, will act to disdisperse any gases generated. Again, if there is any doubt about the effectiveness of the seal around the battery compartment, open the windows during regenerative braking. 
2 WHY ARE STIBINE AND ARSINE GASES IMPORTANT TO DESIGNERS AND USERS OF ELECTRIC VEHICLES?

Basic facts about lead-acid battery composition, operation and charging for transportation vehicles, and health effects data or arsine and stibine are presented here. The conditions likely to initiate production and release of the hydrides $\left(\mathrm{AsH}_{3}\right.$ and $\left.\mathrm{SbH}_{3}\right)$ along with $\mathrm{H}_{2}$ are described as a basis for the procedures outlined in Sec. 1.

\subsection{PRESENCE OF THE METALS IN THE LEAD-ACID BATTERY}

Currently available lead-acid batteries for transportation use lead electrodes alloyed with antimony ( $\mathrm{Sb}$ ) and arsenic (As), among others, with sulfuric acid electrolyte. The arsenic is present in small amounts, as an impurity and as a corrosion inhibitor, generally less than $0.3 \%$ of the electrode weight. Antimony, added for strength and longer battery life, varies in content among batteries by different manufacturers and ranges between 2 and $6 \%$. The exact value of the $\mathrm{Sb}$ percentage is generally considered proprietary because of the importance of $\mathrm{Sb}$ to efficiency and life.

As a result of anodic corrosion during charge, the $S b$ and As dissolve in the electrolyte and migrate from the positive electrode to the negative. Above certain voltages both metals in the acid environment will tend to form hydrides that can then escape as gases at the negative electrode along with free $\mathrm{H}_{2}$. The exact mechanisms governing both the migration to the anode and the release rate of the hydrides, $\mathrm{SbH}_{3}$ and $\mathrm{AsH}_{3}$, are not well understood.

\subsection{THE EQUALIZATION CHARGE IN ELECTRIC VEHICLE BATTERIES}

A proper recharge of lead-acid battery requires, in addition to the replacement of the ampere-hours discharged, an excess of about $20 \%$ of the discharged capacity. This is termed an overcharge. Periodically, an equalization charge is required to balance the state of charge among all cells within a battery 
pack. The specification for charging, overcharging, and equalization charging is strongly dependent on the battery system, time allowed for charging, and the charger available. However, a battery will typically be recharged at a constant current until the voltage rises to a pre-set maximum $(2.4$ to $2.6 \mathrm{~V})$. Then, the voltage is maintained constant until either a fixed time has elapsed or a fixed level of current, the finish rate, is reached; this constitutes a period of over-charge within a typical recharge. Equalization charging is applied after a fixed number of cycles (typically 10 cycles or a week of deep cycles) by charging at the finish rate for a fixed time or until a pre-set specific gravity is reached in all cells. There is no standardized charging regime applicable to all battery systems. A normal recharge takes $8-10 \mathrm{~h}$ depending on the depth of discharge. The equalization charge is usually done after a normal recharge; the whole period of charge plus equalization lasts $10-16 \mathrm{~h}$, depending on the depth of discharge and time since the last equalization.

It is during the overcharge and the equalization charging that the battery voltage is high enough to generate gases, among them stibine, arsine, and hydrogen. It has been shown experimentally (1) that the rate of stibine generation is dependent on the pre-set voltage per cell during overcharge and equalization charging. However, the hydrogen concentration in the gases is also dependent on the pre-set voltage. The management of hydrogen concentration in ambient air is essential to lessen the risk of explosion, as the lower limit of flammability is $4 \%$ at standard temperature and pressure conditions. Fundamentally, gas evolution during recharging and equalization charging should be kept to a minimum not only to minimize the stibine and hydrogen evolution, but also to avoid premature failure of the battery. The rate of hydride gas evolution during equalization charge has been measured for utility cells (1), but not sufficiently for electric vehicle (EV) battery cells. Calculations based on the utility cell rates indicate that ambient concentrations in a ventilated garage are likely to be on the order of magnitude of the occupational exposure standard (2). There is much more $\mathrm{Sb}$ than As in both utility and EV batteries - from 20 - 50 times more. Stibine is evolved from batteries at greater rates than arsine, proportionately more 
than its presence in the electrodes. Although EV batteries are constructed somewhat differently than utility storage batteries, and are charged/discharged on a different cycle, the stibine rates will still remain higher. Thus, measurement of $\mathrm{SbH}_{3}$ is most important, as $\mathrm{AsH}_{3}$ will be lower, or at worst in the same ratio as the occupational exposure standards.

\subsection{HEALTH EFFECTS OF STIBINE AND ARSINE}

\subsubsection{Pathways to Humans and Toxic Levels}

Stibine and arsine are toxic gases which can be generated by 1) the action of acid on antimony or arsenic-containing compounds, 2) the action of water on metallic arsenides, and 3) the charging of lead-acid batteries containing antimony and arsenic as electrode components. Stibine is relatively unstable in air, while arsine is stable in air. Exposure via inhalation, as opposed to oral ingestion or skin contact, is the exposure mode of concern to humans. Animal experiments indicate that upon entry into the body, stibine and arsine concentrate mainly in the red blood cells and the liver $(3,4)$. Elimination of antimony or arsenic following exposure to these gases appears to be fairly rapid. Guinea pigs eliminate approximately half of the deposited antimony within $45 \mathrm{~min}$ of exposure to $25 \mathrm{ppm}$ stibine (3). In the case of arsine, mice eliminated $55 \%$ of the initially retained arsenic by $24 \mathrm{~h}$ and excretion of the remaining fraction was slower (4).

Exposure to arsine at $250 \mathrm{ppm}$ for $0.5 \mathrm{~h}$ is considered lethal to humans $(5,6)$. Acutely toxic levels of stibine are similar to those of arsine, as indicated by early animal experiments (7). Three symptoms of acute exposure, characteristic of arsine poisoning, consist of abdominal pain, dark-red urine, and jaundice (8). Dark-red urine usually appears 4 to $6 \mathrm{~h}$ after inhalation of high levels of the gas and is due to a breaking of red bood cells. This is followed at 24 to $48 \mathrm{~h}$ by the appearance of jaundice. Death, if it occurs, is usually due to kidney failure caused by the breaking of red blood cells and the accumulation of hemoglobin in the kidneys. Human exposure data consist of reports of occupational exposure to arsine; stibine exposure cases. 
have not been reported. Treatment for severe acute arsine poisoning consist of 1) exchange transfusions to replace red blood cells, and 2) dialysis, if renal failure occurs $(5,9-12)$.

The question more relevant to persons in contact with lead-acid batteries and the gases released during charging is the question of responses to low levels of stibine or arsine. Data on low level responses to stibine are not available. In the case of arsine, C. A. Nau exposed guinea pigs for 1 to $3 \mathrm{~h}$ daily for up to $144 \mathrm{~h}$ at concentrations ranging from 5 to 20 times the Threshold Limit Value (TLV), i.e., from $0.5 \mathrm{ppm}$ to $2.0 \mathrm{ppm}$ (13). He described a decrease in red blood cell count and hemoglobin levels to near $80 \%$ of the original values, which were maintained during exposure. Other blood cell changes were also mentioned, but the changes were presented in a descriptive way with no quantitative data. The changes were ones that would not be expected to produce any symptoms of exposure.

Two articles were found on human exposure responses that might be anticipated under conditions of chronic exposure to low levels of arsine. In one case, slight decreases in hemoglobin levels were observed in men exposed for six days to an atmosphere containing arsine (6). The arsine concentration was not measured, but was such that men exposed to this same atmosphere for 8 months were not acutely 111; however, the striking reduction of hemoglobin and red blood cell levels prompted treatment with blood transfusions. The 5 men exposed for six days had no symptoms that were common to all of them, but headache and shortness of breath were listed as symptoms present in 4 and 3 of the 5 cases, respectively.

In the second report (14) exposure to arsine occurred at a zinc smelter from a leaching operation for the recovery of cadmium. Two workers had symptoms of acute exposure, so ambient air monitors and a program of periodic blood tests of workers were instituted. Arsine levels inside the tanks for leaching were measured at 2 to $3 \mathrm{ppm}$, with no arsine detectable outside the tanks. Monitoring indicated a flaw in the process, producing higher ambient concentrations near the location of the two most affected workers (who both recovered). The general exposure level must, however, have been very low. 
The hemoglobin levels of the other workers exposed to arsine gradually rose from $85 \%$ to a normal level of about $90 \%$ over a period of 40 weeks following installation of positive exhaust ventilation. This human body response is one which is clinically measurable but produces no symptoms that the exposed person can detect. (The general plant population had hemoglobin levels of 92\%.) The blood response in the exposed workforce is therefore characterized as slight and reversible with positive exhaust ventilation. Information on human exposure to low levels of stibine are not available, and the toxicity of stibine must. be inferred by its analogy to arsine.

Standards have been set for occupational exposure to both arsine and stibine. The Threshold Limit Value - Time Weighted Average (TLV-TWA) represents a limit on the average exposure level that may be experienced over a period of eight continuous hours of exposure. The TLV-TWA for $\mathrm{SbH}_{3}$ is $0.1 \mathrm{ppm}$; for $\mathrm{AsH}_{3}$ it is $0.05 \mathrm{ppm}$. Periods of exposure to concentrations higher than the TLV-TWA are considered acceptable if the average exposure over eight hours does not exceed the TLV-TWA. For both $\mathrm{SbH}_{3}$ and $\mathrm{AsH}_{3}$, the American Conference of Government Industrial Hygienists, who set the TLVs (15), recommends excursion limits for exposure to both gases. These excursion limits (TLV-STEL, Short Term Exposure Limit) are greater than the TLV-TWA by a factor of three. For $\mathrm{SbH}_{3}$, the limit is $0.3 \mathrm{ppm}$ or $1.5 \mathrm{mg} / \mathrm{m}^{3}$. For $\mathrm{AsH}_{3}$, it is $0.15 \mathrm{ppm}$ or $0.6 \mathrm{mg} / \mathrm{m}^{3}$. Unless concentrations exceed these excursion levels, the risk of exposure to these gases can be minimized by keeping exposures short.

\subsubsection{Source of Health Exposure Data}

The reports of human exposure to arsine come primarily from metal refining and smelting industries (8). With the exception of the 1919 report of sailors poisoned by off-gassing during battery charging on a submarine (16), there is no report of exposure from users of vehicle lead-acid batteries. Use and charging of in-plant vehicles (e.g., for warehousing) and military electric vehicles have not provided any reported incidents of measurable effects of exposure to stibine or arsine. Some of the industries related to various steps in the recovery of materials and fabrication of lead-acid batteries 
have contributed to the data on arsine exposure; these impacts are of concern when examining the long range future of lead-acid batteries for large sectors of the transportation vehicle market. It is in that context that the manufacturing and mining occupacional health issues will be addressed (2).

\subsection{LONG TERM PROSPECTS FOR LEAD-ACID BATTERIES IN ELECTRIC VEHICLES}

Over the next twenty years most researchers expect lead-acid batteries to be supplanted by one of the nickel batteries and eventually by one of the batteries now classed as advanced. These batteries have theoretical energy efficiencies and densities superior to that of lead-acid. However, there is now no production capacity for any of the alternative batteries sufficient to satisfy the electric vehicle market in the next five years. The electric vehicle to be purchased as part of the DOE Demonstration Project for the first two and possibly three groups of purchases, representing $800-2500$ vehicles, are a significant portion of the EV market for the next five years. Each vehicle will be operated at least two years under the Project, building experience with the operation of EVS. Resolution of health and safety issues for this Project is essential. Further, any delays in the R\&D schedule for other batteries extends the use of lead-acid batteries, as will advances in the Improved State of the Art (ISOA) Pb-Acid Battery program. 
3 RESEARCH TO RESOLVE REMAINING QUESTIONS

\subsection{CRITERIA FOR EXPERIMENTS}

Preliminary calculations and data collection do indicate a need for definitive empirical measurement of actual exposure levels from in-use electric vehicles under controlled conditions. It is clear that data collection equipment must be able to detect relatively low levels in air, near the 8-hour TLV of 0.1 ppm for stibine and $0.05 \mathrm{ppm}$ for arsine. Although there remain many data items of interest to long term battery research and development regarding the function of $\mathrm{Sb}$ and $\mathrm{As}$ in the battery, the experiments to be set up now must be focused on resolution of driver and maintenance personnel-related concerns for batteries in use in electric vehicles. In-vehicle, in-garage, and on-theroad conditions are the setting for the data collection; actual manufacturersupplied equipment such as chargers and ventilating fans are to be used as directed by the vehicle manufacturer. Room size and ventilation rates will be typical of electric vehicle user situations - e.g., a one and a half car garage used for overnight recharge of a personal electric vehicle or a 40-van garage housing a service vehicle fleet that is half electric, half gasoline powered. The regenerative braking situation will also be examined.

Several other points need to be addressed in these exposure data experiments. The off-gassing rate changes over the length of a recharge/overcharge cycle, based on the stationary battery cell experience, differences in ambient levels during the cycle or at the end of it, must be examined. Electric vehicle users need to know whether there are likely to be higher ambient levels at the start of the equalization charge or at the end, or if the ventilation system in the bullding has falled, yet the batterles continue to be charged.

It is probably not necessary to test all presently manufactured batteries and vehicles in combination. One or two commonly used batteries in a small number of typical electric vehicles meeting the DOE performance standards in all respects (17) will provides enough breadth to characterize currently available vehicles. Further, once the testing procedure is set up for experiments, others can repeat them. 


\subsection{EXPERIMENTAL - DESIGN AND SCHEDULE}

To satisfy the immediate need for definitive information for the demonstration program, the following series of tests will be conducted:

The tests will include 1) ambient-air monitoring inside EV at two locations and one location at exhaust, 2) in-garage ambient air testing in three locations, and 3) direct monitoring of charge gas from three randomly chosen cells. Tests 1 and 2 will be repeated under conditions corresponding to charging with no positive garage ventilation, respectively. In addition, similar tests will be conducted on board electric vehicleș during driving and will include monitoring ambient air at two locations inside the vehicle and one location near the exhaust. : The gases will also be monitored from three cells randomly selected. The cell gas will be collected every 10 minutes to generate a $\mathrm{SbH}_{3} / \mathrm{AsH}_{3}$ generation profile for mass balance computations. The details of the tests are given in Table I.

Each test will be done twice (for a total of 16 tests). The tests will take 36 working days for two persons. Elapsed time from Feb. 1, 1980 will be a minimum. of three months, assuming only reasonable delays. Environmental data, e.g., temperature and humidity, and the status of vehicle and battery systems (e.g., specific gravity) will be collected with each experiment. 
14

Table I Stibine/Arsine Field Test During In-garage Charging and On-board EV-in-drive During Regenerative Braking/Charging of Lead-Acid Batteries

\begin{tabular}{ll}
\hline TESTS & COMMENTS \\
\hline In-garage Charging and Equalization & $\begin{array}{l}\text { Battery electrical and acid- } \\
\text { sp.gve data to be obtained }\end{array}$ \\
$1 \quad$ Sample 2 places inside EV plus 1 near exhaust, $8 \mathrm{~h}$ & Worst case \\
2 Repeat (1) without EV exhaust fan, $8 \mathrm{~h}$ & Worst case \\
3 Ambient air 3 locations outside EV, $8 \mathrm{~h}$ & $\begin{array}{l}\text { Provides gas rate profile } \\
\text { for mass balance }\end{array}$ \\
4 Repeat (3) with garage ventilation off, $8 \mathrm{~h}$ & \\
5 Direct collection from 3 cells, 10 min &
\end{tabular}

EV-In-Drive During Regenerative Braking

6. Ambient air inside $\mathrm{EV}$

windows open \& exhaust on -3 locations $\sim 20 \mathrm{~min}$

7 Repeat (6) with windows closed $\sim 20$ min.

Worst case

8 Direct collection from 3 cells - windows open,

Mass balance ventilation system on, $10 \mathrm{~min}$ 


\subsection{ANALYTICAL PROCEDURES}

The ANL stibine and arsine monitoring field kit (SAMFK) (18) will be used for collection of $\mathrm{SbH}_{3} / \mathrm{AsH}_{3}$ gases. The absorber solution will be analyzed for $\mathrm{Sb}$ and $\mathrm{As}$.

There are two methods for determining $\mathrm{SbH}_{3}$ in the absorber solution. In the first technique, hydrogen flame atomization is combined with atomic absorption spectrophototometry. The estimated sensitivity for this method is sufficient to detect antimony in solution at levels of $0.05 \mu \mathrm{g} / \mathrm{ml}$, which is equivalent to 0.05 ppmv for 10 minutes of collection (10 L air sampled). This procedure needs a modest development effort by the Analytical Chemistry Laboratory at ANL. The detection sensitivity for $\mathrm{AsH}_{3}$ is similar. In the second technique, a spectrophotometer is used for colorometric determination of antimony in the absorber solution after an $8 \mathrm{hr}$ collection. For this method, a detection sensitivity of about 0.05 ppmv for $\mathrm{SbH}_{3}$ is expected. The precision for both types of analytical determination can be set at $10 \%$.

It is recommended that $\mathrm{SbH}_{3}$ be determined on-site using SAMFK - spectrophotometer, and that samples of absorber solution be sent to the ANL Analytical Chemistry laboratory for determination of $\mathrm{SbH}_{3}$ and $\mathrm{AsH}_{3}$. 
ACKNOWLEDGEMENTS

The research and development work in the electric and hybrid vehicle program provides the basis for this summary statement of how to address posisible toxic gas emissions from overcharge. Many individuals in DOE, including $W . J$. Dippold and D. P. Maxfield, and at Argonne (M. J. Bernard, L. Coleman, J. R. Gasper, P. A. Nelson) have contribute significantly to this effort. The authors however bear responsibility for any omissions or errors.

\section{ACRONYMS}

$\begin{array}{ll}\text { ANL } & \text { Argonne National Laboratory } \\ \text { DOE } & \text { U. S. Department of Energy } \\ \text { EV } & \text { Electric Vehicle } \\ \text { ppmv } & \text { parts per million, volume } \\ \text { SAMFK } & \text { Stibine/Arsine Monitoring Field Kit } \\ \text { STEL } & \text { Short Term Exposure Limit } \\ \text { TLV } & \text { Threshold Limit Value } \\ \text { TWA } & \text { Time Weighted Average }\end{array}$




\section{REFERENCES}

1. R Varma and N. P. Yao, Stibine and Arsine Generation from a Lead-Acid Cell During Charging Modes under a Utility Load-Leveling Duty Cycle, Argonne National Laboratory, ANL/OEPM-77-5 (Mar 1978).

2. S. J. LaBelle, Environmental Assessment for the Electric and Hybrid Vehicle Demonstration Project Performance Standards and Financial Incentives, Argonne National Laboratory, ANL/EES-TM-22 (Oct 1978), also published as DOE/EA-0075 (Mar 1979).

3. R. E. Smith et al., The Tissue Distribution of Radioantimony Inhaled as Stibine, J. Lab. Clin. Med. 33: 635-643 (1948).

4. G. A. Levvy, A Study of Arsine Poisoning, J. Exp. Physiol. Med. Sc1. 34: 47-67 (1947).

5. R. Muehreke and C. L. Pirani, Arsine-induced Anuria: A correlative Clinicopathological Study with Electron Microscope Observations, Ann. Intern. Med. 68: 853-866 (1968).

6. F. M. R. Bulmer et al., Chronic Arsine Poisoning among Workers Employed in the Cyanide Extraction of Gold: A Report of Fourteen Cases, J. Ind. Hyg. Toxicol. 22: 111-124 (1940).

7. A. Stock and 0. Guttman, Uber den Antimonwasserstoff und das Gelbe, Antimon. Ber. Dtsch. Chem. Ges.' 37: 885-900 (1904).

8. B. A. Fowler and J. B. Weissberg, Arsine Poisoning, New Eng. J. Med. 291: 1171-1174 (1974).

9. A. E. DePalma, Arsine Intoxication in a Chemical Plant: Report of Three Cases; J. Occup. Med. 11: 582-587 (1969).

10. R. Neuwirtova et al., Acute Renal Failure following an Occupational Intoxication with Arsine ( $\left.\mathrm{AsH}_{3}\right)$ Treated by the Artificial Kidney, Act. Med. Scand. 170: 535-546 (1961).

11. B. Nielson; Arsine Polsoning in Metal Refinining Plant: Fourteen Simultaneous Cases, Acta Med. Scand. (Suppl.) 496: 1-31 (1968)。

12. S. P. Wilkinson et al., Arsine Toxicity Aboard the Asia-Freighter, Br. Med. J. 3: 559.-563 (1975).

13. C. A. Nau, W. Anderson and R. E. Cone, Arsine, Stibine, and Hydrogen Sulfide--Accidental Industrial Poisoning by a Mixture, Ind. Med。 13: 308-310 (1944).

14. G. A. Johnson, An Arsine Problem, Am. Ind. Hyg. Qt. 14: 188-190 (1953). 
15. Threshold Limit Values for Chemical Substances in Workroom Air, adopted by American Conference of Government Industrial Hygienists for 1979, Cincinnati, Ohio.

16. S. F. Dudley, Toxic Anemia from Arseniuretted Hydrogen Gas in Submarines, J. Ind. Hyg. $1,215-232$ (1919).

17. Electric and Hybrid Vehicle Research, Development and Demonstration Program: Performance Standards, Federal Register 44 (174): 52140-4 (Sept 6, 1979).

18. R. Varma, G. Cook, and N. P. Yao, Development and Testing of Stibine/ Arsine Field Monitoring Kit, ANL/OEPM-78-4 ( in press) (1980). 